\title{
Identifikasi Potensi Kopi Jahe Sebagai Oleh-Oleh Khas Betawi
}

\author{
Heni Pridia Rukmini Sari ${ }^{\mathrm{a}, 1, *}$ \\ ${ }^{\text {a}}$ Program Studi Hospitaliti dan Pariwisata - Institut Stiami \\ ${ }^{1}$ Email: heni.pridia@gmail.com* \\ * corresponding author
}

\section{ARTICLE INFO}

\section{Keywords}

sustainability tourism,

gastronomy tourism,

SWOT analysis,

souvenirs

\begin{abstract}
Jakarta is a melting pot of cultures from various ethnics and also foreign countries. Even so, Jakarta also has a native population, namely the Betawi ethnic group, who now mostly live on the outskirts of Jakarta because of the development of the capital region. Betawi cuisine is part of an integral Betawi tribe. This Betawi culinary can become one of Indonesia's superior cultural potentials that has special characteristics, high quality and identity, and has a creative ethos and differs creativity, as well as added value economically, technologically and culturally.

This research identifies the potential of Betawi culinary to support Jakarta tourism. In addition to culinary, souvenirs can be brought in the form of food and crafts that reflect cultural character. The research method was carried out using a qualitative approach with a grounded theory method. Researchers conducted a desk study activity on culinary tourism potential, compiled a list of Betawi culinary potentials, confirmed the potential of the interviewees (snacks, main food, lunch, dessert, drinks) and made conclusions. The report preparation method is carried out using literature study, field observations, and discussions with informants in the field from the Betawi Women's Association, Betawi Cultural Institute (LKB), Betawi culinary entrepreneurs, and the Jakarta Tourism Office.

The achievement of this research is the identification of Ginger Coffee to be used as a potential for souvenirs typical of Betawi which contain locality elements as a basis for developing tourism destinations in Jakarta in particular and Indonesia in general.
\end{abstract}

\begin{abstract}
ABSTRAK
Jakarta merupakan ibukota negara Indonesia yang merupakan melting pot budaya dari beragam etnik Nusantara dan juga mancanegara. Meskipun begitu, Jakarta juga memiliki penduduk asli, yaitu etnis Betawi yang kini kebanyakan sudah berdiam di pinggiran Jakarta karena perkembangan pembangunan daerah ibukota. Kuliner Betawi yang merupakan bagian dari suku Betawi yang terpisahkan. Kuliner Betawi ini bisa menjadi satu potensi budaya unggulan Indonesia yang memiliki sifat khas, bermutu tinggi dan beridentitas, dan beretos kreatif dan mendifusikan kreativitas, serta bernilai tambah secara ekonomi, teknologi dan kultural.

Penelitian ini mengidentifikasikan potensi kuliner Betawi untuk menjadi penunjang pariwisata Jakarta. Selain kuliner, pendukung daya tarik wisatawan yaitu oleh-oleh khas yang dapat dibawa sebagai buah tangan berupa makanan dan kerajinan yang mencerminkan karakter budaya. Metode penelitian dilakukan dengan pendekatan kualitatif dengan metode grounded theory. Peneliti melakukan aktivitas desk study potensi wisata kuliner, menyusun daftar potensi kuliner Betawi, melakukan konfirmasi potensi pada narasumber (kategori kudapan, makanan utama, makanan sepinggan, makanan penutup, minuman) dan menyusun kesimpulan. Metode penyusunan laporan dilakukan dengan menggunakan studi penelusuran pustaka, observasi lapangan, dan diskusi dengan informan di lapangan dari Persatuan Wanita Betawi, Lembaga Kebudayaan Betawi (LKB), wirausahawan kuliner Betawi, dan Dinas Pariwisata Jakarta.

Capaian penelitian ini adalah identifikasi Kopi Jahe untuk dijadikan sebagai potensi oleh-oleh khas Betawi yang mengandung unsur kelokalan untuk acuan dasar pengembangan destinasi pariwisata di Jakarta khususnya dan Indonesia pada umumnya.
\end{abstract}




\section{PENDAHULUAN}

Pariwisata merupakan salah satu sektor dengan pertumbuhan perekonomian yang sangat cepat. UNWTO (2015) mengindikasikan bahwa di tahun mendatang akan terjadi penyerapan tenaga kerja yang cukup besar di industri pariwisata. Orang berwisata untuk mencari suasana lain dibandingkan dengan kehidupan sehariharinya. Seperti dikatakan dalam UU No. 9 Tahun 1990 pariwisata adalah segala sesuatu yang berhubungan dengan wisata, termasuk pengusahaan obyek dan daya tarik wisata pada destinasi pariwisata serta usahausaha yang terkait di bidang tersebut. Pariwisata selalu berkaitan dengan destinasi pariwisata dan merupakan bagian penting dari sistem pariwisata. Metelka (1990:46) mengatakan bahwa destinasi pariwisata sebagai lokasi geografis tempat seseorang bepergian; Gunn (1994) melihat destinasi pariwisata sebagai area pasar perjalanan wisata dan merujuk pada zona tujuan perjalanan yaitu area geografis yang meliputi pembangunan wilayah dan masyarakat dalam rangka memuaskan tujuan perjalanan wisatawan. Destinasi pariwisata dapat dijelaskan pada skala yang berbeda mulai dari level desa sampai wilayah kota atau resort, situs khusus dan bahkan hanya berwujud atraksi khusus yang dikunjungi wisatawan. Keseluruhan atribut tersebut merupakan sarana untuk mendatangkan wisatawan berkunjung.

Pengaruh globalisasi membuat terjadinya peningkatan permintaan wisata dan kompetisi dari berbagai destinasi di dunia. Destinasi pariwisata saling berlomba memperebutkan pasar dengan memberi pembedaan pada masing-masing produk yang dimilikinya. Haven-Tang and Jones (2006) menyatakan bahwa setiap destinasi pariwisata harus memiliki fokus dengan menonjolkan kekhasan setempat dengan menggunakan atribut lokal dengan menampilkan inovasi, produk dan merek baru, yang dapat meningkatkaan jumlah penjualan yang lebih unik.

Makanan seperti diakui oleh pemerintah, kalangan bisnis, dan akademisi merupakan bagian integral dari sebuah produk pariwisata. Makanan bukan lagi menjadi sekadar produk, tapi sudah menjadi pembeda terhadap suatu destinasi pariwisata (distinctive competitiveness). Makanan lokal merupakan elemen penting untuk membantu menciptakan pengalaman baru bagi wisatawan dan meningkatkan daya tarik destinasi. Produk lokal akan menambah pengalaman wisata yang unik dan memberikan motivasi bagi pengunjung untuk datang ke lokasi. Wisatawan bahkan mungkin memiliki keinginan untuk tinggal lebih lama di satu tempat karena ketersediaan produk makanan dan kegiatan terkait. Pariwisata lalu menjadi outlet penjualan tambahan bagi produsen makanan sehingga merangsang dan merevitalisasi ekonomi lokal.

Kopi Jahe merupakan minuman kopi aromatik yang biasanya disajikan saat sore hari atau saat ada tamu yang berkunjung pada keluarga Betawi. Kopi Jahe terbuat dari minuman kopi yang direbus dengan aneka rempah seperti cengkih, kayumanis, garda mangga (temu mangga), daun pandan, dan jahe. Saat akan disajikan, Kopi Jahe ditambahkan dengan susu kental manis dan gula. Dihidangkan selagi hangat sehingga dapat mengusir udara sore yang mulai dingin. Kopi Jahe juga berkhasiat untuk kesehatan karena penggunaan rempah-rempah ke dalamnya. Di antaranya jahe yang dapat meningkatkan kekebalan tubuh dan mengurangi gangguan pencernaan (tempo.co, 2017).

Symons (1999) mengatakan makanan lokal adalah komponen fundamental dari atribut destinasi, menambah kaya atraksi dan keseluruhan pengalaman wisata. Konsumsi makanan ternyata merupakan aspek integral dari pengalaman berwisata, tidak hanya masalah rasa dan penyajian, namun juga oleh pengalaman menikmati tempatnya. Hampir dapat dikatakan semua untuk makan. Hal inilah yang membuat makanan menjadi konstituen penting dari produksi serta konsumsi pariwisata.

Wisata kuliner oleh-oleh makanan khas bisa menjadi salah satu daya wisata suatu tempat yang mampu mendatangkan manfaat yang besar terhadap perekenomian masyarakat. Contohnya adalah Yogyakarta yang memiliki makanan dan oleh-oleh khas, seperti bakpia, geplak, yangko, gudeg, jadah tempe, kipo, dan masih banyak lagi. Bisnis oleh-oleh khas Yogyakarta ternyata memberikan keuntungan ekonomis bagi masyarakat. Berdasarkan data Dinas Perindustrian Perdagangan dan Koperasi (Disperindagkop) DIY, sepanjang tahun 2007 sedikitnya 46\% dari total 75.140 industri kecil di Yogyakarta bergerak di bidang pengolahan makanan (Pusat Peluang Usaha dan Promosi Bisnis UMKM, 2009). Hal ini secara tidak langsung menunjukkan dampak positif pariwisata terhadap pertumbuhan bisnis makanan dan oleh-oleh khas Yogyakarta. Kondisi tersebut tentu memberikan efek positif terhadap perekonomian masyarakat karena umumnya bisnis kuliner oleh-oleh masih bersifat padat karya.

Fakta ini yang menjadi alasan kuat bahwa Kopi Jahe dapat dijadikan sebagai salah satu minuman lokal Betawi yang memiliki potensi untuk dikembangkan sebagai sebagai minuman khas Betawi. Kopi Jahe juga dapat dijadikan sebagai oleh-oleh khas Betawi yang akan selalu mengingatkan wisatawan akan Betawi. Penetapan Kopi Jahe sebagai minuman oleh-oleh khas Betawi dilakukan berdasarkan khasanah local wisdom dengan memelihara keragaman dan kedalaman produk serta memanfaatkan sumber daya lokal. Melalui 
pangan dan budaya kuliner lokal tersebut maka diharapkan dapat mendukung pengembangan ekonomi lokal dan kesejahteraan rakyat. Pengembangan destinasi wisata kuliner patut melibatkan masyarakat secara luas, sehingga secara strategis dapat mengintegrasikan pariwisata dalam pengembangan wilayah dengan memadukan antar sektor dan antar pemangku kepentingan. Oleh karena itu, penulis memandang perlu melakukan penelitian untuk mengidentifikasi potensi Kopi Jahe sebagai oleh-oleh khas Betawi dengan rumusan sebagai berikut:

1. Menemukenali kelebihan dan kekurangan dari Kopi Jahe.

2. Menganalisis peluang pengembangan potensi Kopi Jahe dengan pendekatan konservasi, preservasi dan rehabilitasi untuk menciptakan pembangunan pariwisata berkelanjutan.

\section{TINJAUAN PUSTAKA}

\section{Pariwisata dan Makanan}

Pariwisata dan makanan seolah tak bisa dipisahkan. Secara alamiah, makanan adalah produk yang diperlukan secara biologis oleh wisatawan. Makanan juga ternyata bisa menjadi pembeda dari suatu destinasi wisata. Siapa tak kenal dengan gudeg yang merupakan ikon terkenal dari Yogyakarta atau pempek yang identik sebagai makanan khas dari Palembang? Kedua makanan tersebut yang kemudian menjadi identitas dari destinasi tersebut. Bahkan seperti dikatakan oleh Jones dan Jenkins (2002) makanan bisa meningkatkan nilai produk pariwisata inti dan menjadi fokus untuk acara khusus. Makanan juga dapat menjadi penarik pasar untuk segmen tertentu yang jumlahnya tidak besar tetapi memiliki selera yang tinggi dan mampu membayar dalam jumlah yang besar.

Pariwisata makanan sebagaimana dikatakan oleh Hall dan Mitchell (2001) didefinsikan sebagai keinginan untuk menikmati makanan, hidangan atau masakan harus menjadi motivasi utama untuk suatu kunjungan ke suatu destinasi wisata. Jadi, wisatawan berkunjung ke suatu daerah ditentukan oleh ketertarikannya dengan makanan.

Lebih lanjut, Hall dan Mitchell (2005) menyusun kategori berdasarkan motivasi dan perilaku wisatawan dalam menikmati makanan dan tempat menikmatinya.

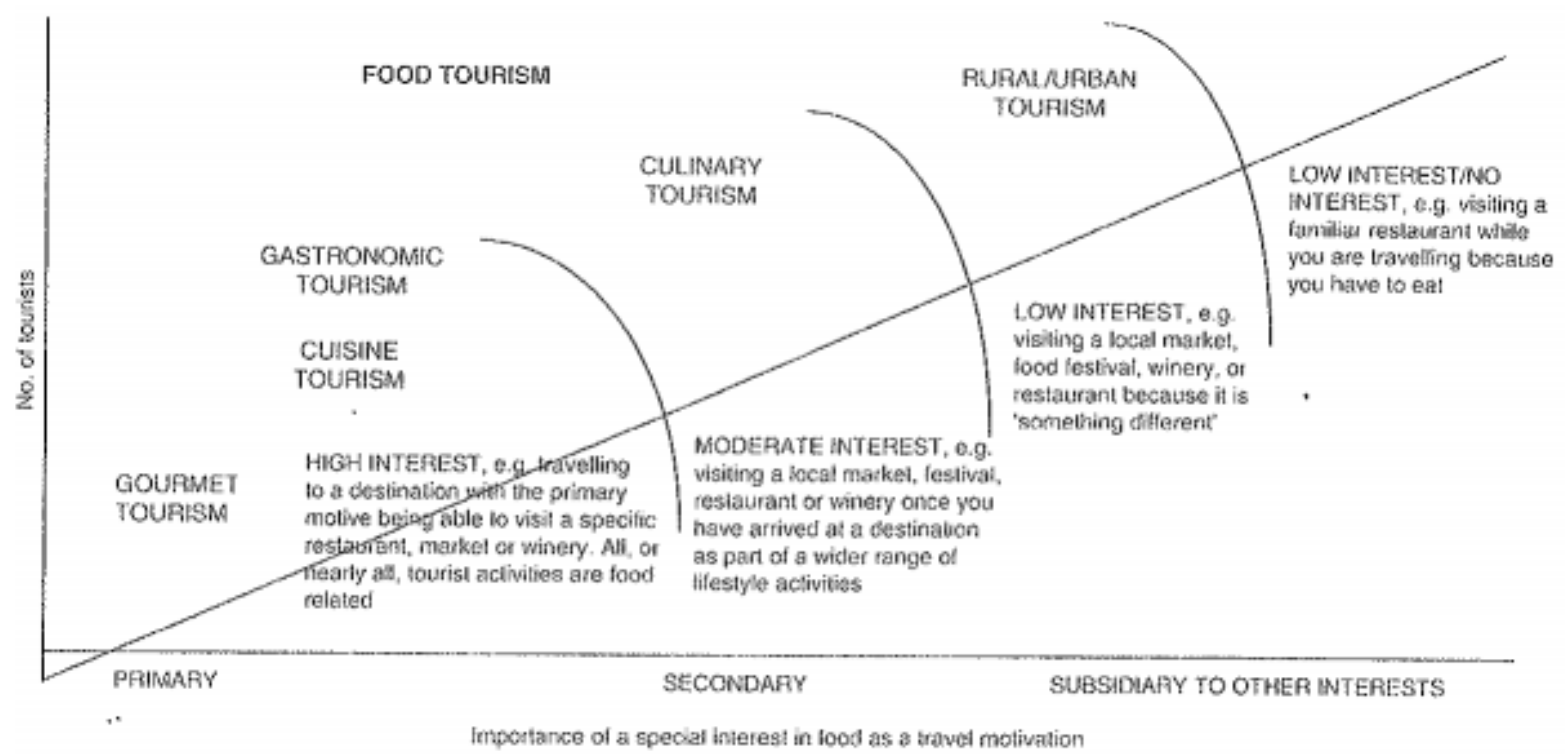

Gambar 1: Kategorisasi Food Tourism berdasar Tingkat Ketertarikan Wisatawan Untuk Berkunjung

Berdasarkan gambar di atas, food tourism dibedakan atas tingkat ketertarikan wisatawan untuk berkunjung ke suatu destinasi wisata. Ketertarikan wisatawan tersebut dibagi menjadi tiga, yaitu primer, sekunder, dan tersier sebagai berikut:

1. Subset pertama meliputi Gastronomic Tourism. Wisata jenis ini dilakukan oleh wisatawan dengan motivasi sangat tinggi terhadap makanan atau minuman tertentu di wilayah tertentu. Keingian berkunjung tersebuat biasanya dihubungkan dengan harga makanan yang tinggi, kategori restoran bintang lima, perkebunan anggur, atau festival.

2. Subset kedua adalah Culinary Tourism. Keinginan untuk mengunjungi festival lokal, pasar, atau perkebunan karena merupakan bagian dari destinasi wisata yang diikutinya. 
3. Subset ketiga adalah Rural/Urban Tourism. Jenis wisata yang memandang makanan sebagai bagian dari kebutuhan hidup. Ketertarikan wisatawan buka pada makanannya, tetapi jika mereka merasakan cita rasa yang tidak enak, mereka masih tertarik untuk mencoba.

Wisata kuliner bisa dikatakan sebagai pariwisata budaya karena berhubungan dengan pelestarian produk pertanian (Corigliano, 2002). Dengan berwisata kuliner, wisatawan akan mendapatkan pengalaman unik saat menikmati makanan. Wisatawan juga mendapatkan pengetahuan soal budaya tertentu yang bisa berhubungan dengan sejarah masa lalu. Keterkaitan antara pariwisata dengan berbagai sektor lainnya digambarkan dengan analogi model wine tourism di bawah ini.

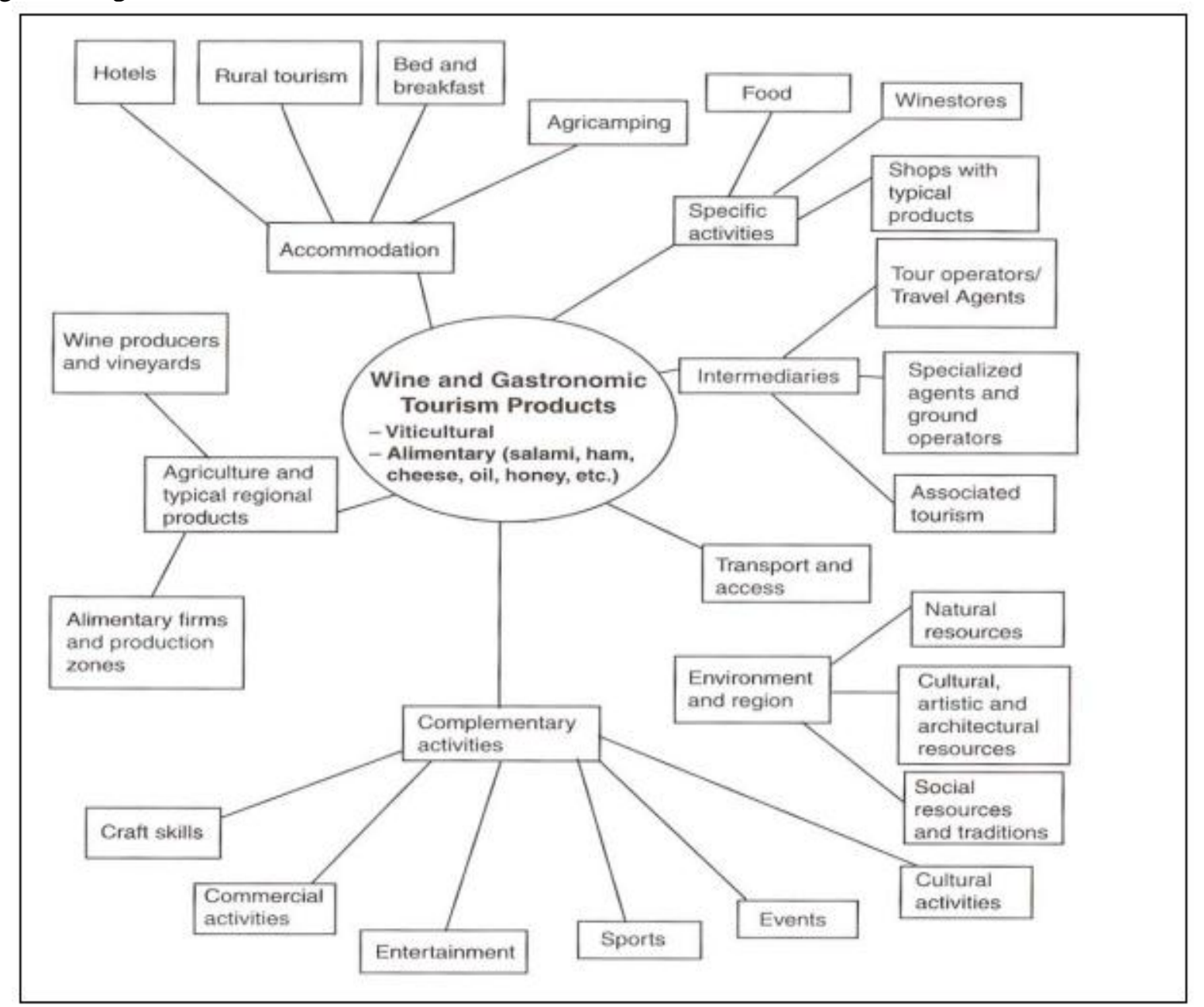

Gambar 1. Keterkaitan Komponen Wine Tourism dengan Sektor Pariwisata Lainnya (Supply System)

(Corigliano; 2002)

Wolf (2002) malah menggambarkan hal sebaliknya. Ia mengatakan bahwa wisata kuliner sekadar perjalanan untuk mencari, dan menikmati, menyiapkan makanan dan minuman namun wisata kuliner juga merupakan misalnya, kunjungan ke pasar, menyiapkan makan khusus di rumah teman, menghadiri acara khusus di restoran terkenal atau makan di restoran lokal. Sedangkan Muhilal (1995) mengatakan makanan tradisional adalah makanan yang telah membudaya di kalangan masyarakat Indonesia, serta telah ada sejak nenek moyang suku Nusantara. Makanan tradisional adalah makanan yang kental dengan tradisi setempat. Lain lagi dengan yang dikatakan oleh Hadisantosa (1993), makanan tradisional sebagai makanan yang dikonsumsi oleh segolongan etnik dan di wilayah spesifik, diolah berdasarkan resep turun temurun. Bahan yang digunakan berasal dari daerah setempat dan makanan yang dihasilkan juga sesuai dengan selera masyarakat lokal.

\section{Destinasi Pariwisata}

Saraniemi dan Kylänen (2011) mengatakan bahwa destinasi pariwisata adalah seperangkat institusi dan orang yang berada pada ruang fisik atau virtual dan terjadi transaksi jual beli baik barang maupun jasa. Pada destinasi pariwisata dimungkinkan ada interaksi antara pembeli dan penjual. Proses transkasi dapat terjadi 
jika penjual dan pembeli telah mencapai kesepakatan terhadap berbagai atribut yang dimiliki. Pada konsep ini, destinasi pariwisata dipandang sebagai konsep pasar.

Sedangkan David and Tozser (2009) menjelaskan bahwa destinasi pariwisata adalah lokasi fisik tempat wisatawan meluangkan waktu minimal satu malam di tempat tersebut. Lokasi tersebut memiliki atraksi wisata, produk dan layanan yang diperlukan oleh wisatawan selama ia tinggal. Destinasi pariwisata memiliki keterbatasan fisik dan administratif, yang ditentukan oleh pengelolaannya serta memiliki citra dan persepsi sebagai daya tarik bagi wisatawan. Dalam konsep ini destinasi pariwisata dipandang sebagai ruang untuk terciptanya interaksi antara masyarakat lokal dan wisatawan (host and guest).

Untuk menjadi sebuah destinasi pariwisata, suatu lokasi atau wilayah harus memenuhi beberapa faktor determinan yang penting (Buhalis, 2000) sebagai berikut:

1. Atraksi wisata, seperti faktor alam dan faktor yang dibuat manusia seperti warisan, budaya, event khusus dan sebagainya.

2. Keterjangkauan, yaitu sistem lalulintas terpadu termasuk di dalamnya jalan, petunjuk jalan, alat transportasi dan sebagainya. Juga pelayanan bagi wisatawan, seperti akomodasi, restoran, dan lain-lain.

3. Paket produk, segala aktivitas yang dapat dilakukan oleh wisatawan selama tinggal seperti pelayanan publik, bank, telekomunikasi dan sebagainya.

Lebih lanjut Presenza, Sheehan, and Ritchie (2005) mengemukakan beberapa karakter dasar destinasi pariwisata, yaitu:

1. Karakter destinasi pariwisata menurut pandangan wisatawan adalah (a) tempat yang dipilih oleh wisatawan sebagai target perjalanannya; (b) daerah yang menyediakan pelayanan bagi wisatawan dan orang yang tinggal.

2. Karakter destinasi pariwisata menurut citra adalah (a) suatu tempat/wilayah yang nyaman secara fisik dan geografis; (b) suatu tempat/wilayah yang memiliki atraksi, produk, pelayanan wisata dan pelayanan pendukung lainnya yang diperlukan bagi para wisatawan untuk tinggal minimal satu hari; (c) suatu tempat/wilayah wisatawan dapat melewatkan waktu minimal satu malam; dan (d) suatu tempat/wilayah yang terdiri dari masyarakat yang peduli untuk bekerja sama satu dengan lainnya.

Sesungguhnya perkembangan destinasi pariwisata tidak dapat dipisahkan dengan karakter sosial ekonomi dari destinasi pariwisata itu sendiri. Bisa dikatakan bahwa pariwisata merupakan fenomena sosial sehingga Hall (2008) menyusun sebuah konsep tentang sistem interaksi orang (people), destinasi (place), dan proses (process) dengan tiap-tiap komponen menjadi jaminan untuk memberikan makna dalam pengembangan destinasi pariwisata secara umum. ini:

Beberapa komponen dalam perkembangan destinasi pariwisata dinyatakan oleh Inskeep (1991) berikut

1. Atraksi wisata adalah kegiatan wisata yang berhubungan dengan lingkungan alam, kebudayaan, dan kegiatan-kegiatan lain yang berhubungan dengan kegiatan wisata yang menarik wisatawan.

2. Akomodasi adalah berbagai macam hotel dan berbagai jenis fasilitas lain yang berhubungan dengan pelayanan kepada wisatawan yang ingin bermalam selama perjalanan wisata yang mereka lakukan. Termasuk dalam komponen ini adalah restoran dan berbagai jenis tempat makan lainnya.

3. Amenitas adalah berbagai fasilitas dan pelayanan wisata dalam perencanaan kawasan wisata. Fasilitas disebut juga pelayanan penyambutan seperti, toko-toko untuk menjual hasil kerajinan tangan dan cenderamata, bank, tempat penukaran uang dan fasilitas pelayanan keuangan lainnya, kantor informasi wisata, pelayanan pribadi (seperti salon kecantikan), fasilitas pelayanan kesehatan, fasilitas telekomunikasi dan sebagainya. Amenitas dapat dikelompokkan dalam dua kategori yaitu amenitas ekonomi dan nonekonomi.

4. Aksesibilitas adalah infrastruktur dan akses transportasi, baik darat, air, dan udara dari dan menuju kawasan wisata, dan transportasi internal yang menghubungkan atraksi utama kawasan wisata dengan kawasan sekitarnya.

Berdasarkan berbagai pendapat tersebut di atas, destinasi pariwisata dapat diartikan sebagai suatu wilayah yang didalamnya terlibat berbagai unsur destinasi, yaitu wisatawan, atraksi wisata, akomodasi, aksesibilitas, dan amenitas.

\section{Oleh-Oleh Untuk Menunjang Daya Tarik Wisata}

Kata kuliner berasal dari bahasa Inggris "culinary" yang diartikan sebagai yang berhubungan dengan dapur atau masakan (Chol, J., \& Shadily, H.: 2000). Masakan tersebut dapat berupa lauk-pauk, makanan (penganan) dan minuman. Klasifikasi makanan menurut penyajiaannya antara lain saji di tempat dan saji 
tidak di tempat, sedangkan menurut daya tahan dibedakan menjadi kurang dari sehari dan lebih dari sehari. Menurut cara penyajiaannya, klasifikasi makanan dibedakan menjadi penyajian formal dan non formal, yaitu sambil menikmati pertunjukan seni dan keindahan alam.

Pada awalnya makanan hanya menjadi salah satu pelengkap kegiatan wisata. Tetapi kemudian berkembang menjadi salah satu bentuk wisata khusus yang disebut dengan istilah wisata makanan atau food tourism. Salah satu bentuk food tourism adalah wisata kuliner.

Wisata kuliner memiliki magnet yang kuat yang dapat menarik wisatawan untuk berkunjung, yaitu keragaman aktivitas kuliner, makanan khas, lokasi yang nyaman dan bersih, desain ruangan (venue) yang unik dan menarik, pelayanan yang baik, pasar yang kompetitif, harga dan proporsi nilai, peluang bersosialisasi, interaksi budaya dengan kuliner, suasana kekeluargaan, lingkungan yang menarik, produk tradisional, nasional dan internasional.

Pendukung daya tarik dalam berwisata kuliner adalah adanya fasilitas oleh-oleh khas daerah berupa makan dan souvenir. Dari arti harfiahnya, oleh-oleh merupakan barang yang diberikan seseorang dari bepergian, bertujuan untuk dikenang (Kamus Besar Bahasa Indonesia, 1994: 801). Klasifikasi oleh-oleh menurut daya tahan dibedakan menjadi barang tahan lama, contohnya produk kerajinan tangan dan bahan tidak tahan lama, contohnya makanan, minuman kaleng. Klasifikasi oleh-oleh produk makanan dibagi menjadi produk roti dan kue, produk kerupuk dan sejenisnya, produk makanan dan masakan olahan, produk makanan ringan. Sedangkan produk souvenir menurut fungsinya dibedakan sebagai peralatan yang dapat digunakan sebagai pendukung kegiatan dan hiasan yang dimanfaatkan sebagai pajangan. Sedangkan menurut kemudahan perpindahannya yaitu movable, souvenir yang relatif ringan dan dapat dibawa kemanamana contohnya makanan dan perhiasan, dan non movable, souvenir yang dimensinya tidak mudah dipindahkan contohnya mebel.

Sebenarnya, wisata kuliner bukanlah hal yang baru. Masyarakat Indonesia pada umumnya memang paling senang berburu santapan menu khas daerah, terutama bila sedang berkunjung ke suatu tempat (Media Indonesia, Agustus 2007). Di Indonesia wisata kuliner menjadi bagian dari jenis wisata secara umum. Baik wisatawan yang datang secara rombongan maupun perseorangan, maupun spontan dan terorganisasi, wisata kuliner merupakan hal yang ingin dicoba. Tidaklah lengkap rasanya berkunjung ke daerah wisata tanpa mencoba kuliner khas daerah. Meskipun belum menjadi produk wisata utama tetapi kehadiran wisata kuliner menjadi subproduk yang mendukung potensi wisata yang sudah ada.

Menurut Bachrul Hakim (2009) Indonesia harus memusatkan perhatian pada kiprah bisnis kuliner di dalam industri pariwisata Indonesia. Menurut Bondan Winarno (2008) industri kuliner di Indonesia memiliki potensi besar untuk dikembangkan menjadi destinasi wisata bagi para wisatawan mancanegara maupun lokal karena keragaman makanan dan minumam khas yang ada disetiap daerah. Kuliner khas Indonesia sangat beragam. Selain dari sisi harga makanan dan minumam yang ada di dalam negeri ini lebih terjangkau dibandingkan dengan makanan luar negeri. Negara tetangga seperti Singapura, Malaysia dan Thailand sudah lebih dahulu mempopulerkan kulinernya. Contohnya di Singapura yang mmiliki suatu tempat bernama Clark Quay dimana orang dapat bersantap dengan nyaman dengan kualitas makanan serta penyajian yang terbaik. Sedangkan kuliner Thailand seperti Tom Yam sudah dikenal baik oleh wisatawan yang datang maupun di luar Thailand.

Dibandingkan dengan negara tetangga, kuliner di Indonesia sangat beragam. Kuliner khas Indonesia tersebar di setiap daerah. Indonesia kaya akan keanekaragaman kuliner memiliki cita rasa yang enak dan dikenal oleh masyarakat luas. Kuliner Indonesia mempunyai kelebihan tersendiri , dengan berbagai budaya bercampur membawa kuliner masing-masing daerah melebur menjadi berbagai resep masakan Indonesia. Orang tidak sulit untuk mencari kuliner yang sesuai pilihan, karena begitu banyak pilihan menu dari pedas, manis, asin, asam, pahit dan dari mulai sayuran, ikan, ayam serta berbagai minuman semuanya ada di menu kuliner Indonesia. Sebagai contoh ada beberapa kuliner Indonesia yang disukai seperti Mie Aceh, Lontong Medan, Rendang Padang, Sayur Asem Jakarta, Rawon Surabaya, Gudeg Yogya, Timlo Solo, Ayam RicaRica Manado, dan lain-lain. DKI Jakarta sebagai ibukota negara Indonesia merupakan kota yang sangat dinamis. Statusnya yang merupakan pintu masuk negeri menjadikan DKI Jakarta mendapatkan banyak wisatawan baik dari dalam negeri maupun luar negeri. Wisatawan tentunya mencari oleh-oleh saat hendak pulang ke tempat asal mereka.

Oleh-oleh diartikan sebagai sesuatu yang dibawa dari bepergian atau buah tangan (KBBI.web.id). M. Banaszkiewicz (2011: 5) menyatakan bahwa oleh-oleh adalah hadiah kecil untuk keluarga atau teman setelah pulang dari bepergian untuk bisa mengeratkan hubungan dengan orang tersebut. Selain itu membeli oleholeh juga merupakan cara untuk mengikatkan diri dan mengingatkan kembali atas perjalanan yang telah dilakukan. Oleh-oleh dapat dibeli untuk aneka maksud dan banyak makna. Seperti dikatakan oleh J. 
Wasilewska (2012) bahwa oleh-oleh dari tempat bepergian dapat berupa kenangan yang disimpan di dalam benak sendiri, karakter diri yang berubah, atau benda-benda yang unik. Kulturowa (2012) mengatakan bahwa ada delapan kategori dari oleh-oleh jika dikaitkan dengan pariwisata, yaitu

1. Barang yang sengaja dibuat untuk memenuhi permintaan akan pasar wisatawan, misalnya peranti makan, pisau.

2. Barang dengan tulisan nama destinasi wisata/ kota, misalnya gantungan kunci, tempelan kulkas, bukaan botol, mug, sendok.

3. Produk makanan, misalnya selai, permen, kacang, rempah-rempah, kue-kue.

4. Barang personal yang dikoleksi dari destinasi wisata, misalnya botol minuman.

5. Barang yang "dicuri" dari destinasi wisata, misalnya cutlery dengan nama restoran, pensil, kopi/teh dalam sachet dengan nama hotel.

6. Barang yang tidak digunakan oleh masyarakat setempat tetapi sengaja diproduksi untuk kepentingan wisatawan, misalnya piring dengan ornamen tertentu.

7. Barang yang dibeli pada saat perjalanan wisata yang akhirnya secara tak sengaja menjadi barang oleholeh, misalnya peta, guide book, buku resep.

8. Dan lain-lain, misalnya tanda tangan orang terkenal saat berada di destinasi wisata.

Lebih lanjut Kulturowa (2012) mengkategorikan oleh-oleh yang berhubungan dengan kegiatan kuliner menjadi:

1. Produk makanan dan minuman, yaitu makanan dan minuman yang harus segera dikonsumsi setelah kembali ke tempat asal, makanan dan minuman yang waktu konsumsinya lebih lama dan dengan waktu kedaluwarsa yang tercantum di kemasannya.

2. Peralatan memasak yang biasa dipakai atau hanya khusus dibuat sebagai barang oleh-oleh. Biasanya dicantumkan nama tempat destinasi.

3. Resep makanan (dalam bentuk buku), guide book soal kuliner, atau kartu menu

4. Foto-foto makanan, buah, atau rempah-rempah yang dijual di toko souvenir atau area pembuatan makanan tersebut.

Yang harus dijadikan sebagai bahan pertimbangan adalah keunikan dari produk kuliner tersebut sehingga wisatawan mau membelinya sebagai oleh-oleh khas tempat tersebut. Toko oleh-oleh daring "World Wide Gifts" menyatakan bahwa makanan itu sangat identik dengan budaya setempat. Karena itu setiap tempat pasti memiliki kekhasan yang tidak ada di tempat lain. Apalagi jika oleh-oleh produk kuliner tersebut dibawa dari tempat yang jauh atau sangat sulit mendapatkannya. Tentu saja tidak setiap makanan dapat dijadikan sebagai oleh-oleh. Oleh-oleh makanan memang paling bagus jika dalam bentuk kering atau dikalengkan. Namun, produk kuliner yang sangat menyiratkan kelokalan daerah tersebut sebetulnya yang paling dicari meskipun produk susah untuk dibawa ke tempat asal. Perbedaan yang sangat jauh antara produk kuliner lokal dengan produk kuliner di tempat asal yang membuat wisatawan menjadi ingin membelinya.

\section{METODOLOGI PENELITIAN}

Penelitian tentang identifikasi potensi Kopi Jahe sebagai oleh-oleh khas Betawi dilakukan dengan pendekatan kualitatif dengan pendekatan grounded theory dan metode snow ball. Dalam pelaksanaan penelitian ini yang akan ditinjau dari tujuan penelitian adalah mengetahui potensi Kopi Jahe jika dijadikan sebagai oleh-oleh lokal khas Betawi dengan menggali dan memahami secara luas permasalahan yang akan dipecahkan. Kesimpulan yang diperoleh melalui in-depth interview dan observasi lapangan.

Kusmayadi (2000:29) mengatakan bahwa penelitian adalah proses berpikir secara logis dan analitis untuk menghasilkan kesimpulan yang benar. Penelitian dilakukan tidak hanya sebatas hubungan antar variabel, tetapi juga melihat fenomena yang terjadi sesungguhnya atau realitas yang sebenarnya tanpa batasan pandangan (Burrel dan Morgan, 1979). Penelitian kualitatif dapat memberikan banyak pilihan cara untuk melihat, menafsirkan, dan memaknai suatu fenomena yang sesungguhnya terjadi di lingkungan sekitar manusia, seperti dengan menggunakan pendekatan grounded theory (Egan, 2002).

Pendekatan grounded theory merupakan metodologi umum analisis terkait dengan pengumpulan data sistematis yang diterapkan dan menggunakan serangkaian metode untuk menghasilkan sebuah teori induktif tentang area substantif (Martin dan Turner, 1986). Jadi dapat dikatakan bahwa pelaksanaan penelitian kualitatif dengan metode grounded theory bertolak belakang dengan penelitian kuantitatif pada umumnya, yang berawal dari teori konseptual menuju kajian empiris, sedangkan grounded theory bermula dari kajian empiris berdasarkan data yang diperoleh menuju ke teori konseptual. Desain penelitian grounded theory merupakan seperangkat prosedur yang digunakan untuk menyusun sebuah teori yang menjelaskan sebuah 
proses mengenai sebuah topik substantif (Egan, 2002). Penelitian grounded theory cocok digunakan dalam rangka menjelaskan fenomena, proses, atau merumuskan teori umum tentang sebuah fenomena yang tidak bisa dijelaskan dengan teori yang ada.

Jenis dan sumber data yang digunakan dalam penelitian ini adalah data kualitatif. Data kualitatif yaitu data yang tidak berupa angka-angka, melainkan diuraikan dalam bentuk kalimat. Adapun data kualitatif meliputi:

1. Data tentang gambaran umum mengenai objek penelitian

2. Data lain yang tidak berupa angka.

Adapun jenis-jenis sumber data yang digunakan dalam penelitian ini dibagi menjadi dua macam, yaitu sumber data primer dan sumber data sekunder. Sumber data primer dalam penelitian ini diperoleh secara langsung dari informan melalui wawancara mendalam (in depth interview), observasi, dan FGD (Focus Group Discussion). Dalam menetapkan informan menggunakan teknik snowball sampling. Snowball sampling adalah teknik pengambilan sampel dengan bantuan key-informan, dan dari key-informan inilah akan berkembang sesuai petunjuknya. Dalam hal ini peneliti hanya mengungkapkan kriteria sebagai persyaratan untuk dijadikan sampel. (Subagyo,2006:31). Dengan teknik snowball sampling ini dipilih komunitas Persatuan Wanita Betawi dan komunitas Lembaga Kebudayaan Betawi sebagai key-informan yang mengetahui tentang kuliner Betawi. Sedangkan data sekunder adalah data yang diperoleh dari pengumpulan data yang menunjang data primer. Data sekunder dalam penelitian ini adalah teks-teks berita mengenai kuliner Betawi, buku-buku, dan dokumentasi lain yang berkaitan dengan penelitian.

Wawancara kepada narasumber yang merupakan pakar/tokoh dan praktisi kuliner Betawi diharapkan dapat memberikan pandangan, masukan, dan saran yang lebih komprehensif karena latar belakang dan pengalaman mereka yang sudah mumpuni.

\section{HASIL DAN PEMBAHASAN}

\section{Sejarah dan Filosofi Kopi Jahe}

Kuliner Betawi sebagai kuliner yang ada dalam masyarakat Betawi dalam perkembanganya mendapatkan pengaruh dengan kuliner etnis lain yang ada di bumi Betawi atau pernah tingal di bumi Betawi. Misalnya, etnis Cina menyumbangkan makanan, seperti bihun, bakmi, bakso, taoge, tauco dan kecap. Selain itu bahan makanan penggunaan bahan dasar tahu dan masakan berbahan ikan seperti ikan Cing Cuan dan sajian dari ikan ekor kuning atau ikan pisang-pisang yang diberi bumbu tauco. Orang Belanda yang cukup lama bermukim di Betawi menyumbangkan seperti masakan semur (smoor), yakni daging (dapat juga tahu, tempe, bahkan jengkol) yang dimasak dengan kecap, risoles, dadar gulung, makaroni, lapis legit dan sebagainya. Orang India menyumbangkan makanan seperti martabak manis dan martabak telur, serta bumbubumbu masak berupa rempah-rempah yang ada di Indonesia juga menyumbangkan nasi uduk. Orang Arab menyumbangkan beberapa jenis masakan seperti nasi kebuli, nasi samin, nasi goreng kambing, gulai tangkar, dan minuman kopi jahe. Selanjutnya, menurut Murni, orang Portugis menyumbangkan kuliner pada kuliner Betawi seperti bolu karamel, talam singkong, dan lain-lain (Thalita, 2018).

Kopi Jahe merupakan minuman tradisional Betawi. Dapat dibuktikan karena minuman ini telah memenuhi kriteria minuman tradisional yang dipaparkan Sastroamidjojo, S., (1995). Kriteria pertama adalah sudah dikonsumsi oleh beberapa generasi. Sejarah Kopi Jahe mungkin bisa dirunut sejak abad ke-18. Saat itu perahu dan rakit dari Tangerang menyusuri Kali Cisadane dan masuk ke Kali Angke dengan membawa bahan bangunan, kain, rempah-rempah, durian, nangka, dan kelapa, menuju ke pusat Kota Lama. Sebelum masuk ke kota, perahu dan rakit-rakit itu biasanya sandar di belakang masjid Langgar Tinggi (berdiri tahun 1829) yang berada di tepi Kali Angke. Masyarakat di sekitar masjid sering mengadakan pesta khitanan, Maulidan, Mikrajan, dan Khatam Al Quran. Saat perhelatan selalu terhidang aneka sajian seperti bubur gandum surba (havermut) berbumbu gulai dengan suwiran halus daging kambing rebus, kurma, rambutan, nangka, durian, dan mangga. Sebagai pelengkap ditemani dengan minuman berupa kopi jahe campur susu (Viva.co.id, 2015). Hingga kini, Kopi Jahe masih sering disajikan sebagai minuman khas warga Betawi meskipun tidak banyak tempat yang menjualnya melainkan hanya di lokasi tertentu seperti di Setu Babakan, Srengseng Sawah, Jakarta Selatan.

Kriteria kedua adalah memiliki cita rasa yang cocok dengan selera masyarakat. Di masa jayanya, Kopi Jahe begitu populer dan disuka, serta termasuk dalam minuman yang selalu disajikan saat perhelatan di kalangan masyarakat Betawi keturunan Arab di Pekojan. Saat itu, Kopi Jahe selalu disajikan sebagai pengiring makan nasi kebuli. 
Kriteria terakhir, adalah menggunakan bahan dan bumbu yang ada di sekitar masyarakat setempat. Syarat ini pun terpenuhi, karena bahan dan bumbu yang digunakan untuk membuat Kopi Jahe justru tersedia banyak di Betawi, seperti kopi, jahe, cengkih, kapulaga, kayumanis, dan daun pandan.

Sajian ini memang tidak sepopuler Bir Pletok yang menjadi ciri khas minuman tradisional masyarakat Betawi. Kopi Jahe memang tidak dikenal di seluruh pelosok Betawi, hanya beberapa wilayah saja yang biasa mengonsumsinya. Begitulah keunikan makanan khas Betawi, sebab etnis Betawi memiliki wilayah penyebaran yang sangat luas. Menurut hasil FGD, Yahya Andi Saputra menjelaskan, setidaknya ada 3 pembagian wilayah Betawi berdasarkan karakter masyarakatnya, yaitu Betawi tengah (atau biasa disebut Betawi kota), Betawi pesisir, dan Betawi pinggir. Karakter masyarakat yang berbeda tentu juga mempengaruhi budaya, pola konsumsi, dan masakan khasnya. Lebih jauh seperti dikatakan oleh Thalita bahwa berdasarkan domisilinya Betawi dibedakan atas tiga kelompok, yaitu:

1. Orang Betawi Tengah yang tinggal di tengah kota.

2. Orang Betawi Pinggir yang tinggal di kampung-kampung dekat kota.

3. Orang Betawi Udik yang tinggal di kampung-kampung yang letaknya jauh dari kota.

Perbedaan lokasi tempat tinggal ini menyebabkan adanya sedikit perbedaan makanan yang disantap. Misalnya, orang Betawi Kota atau Betawi Tengah biasa menyantap sayuran yang disebut sayuran Bogor, seperti wortel, kubis, dan tomat. Orang Betawi yang tinggal di kampung-kampung yang jauh dari kota atau Betawi Pinggir hampir tidak pernah menyantapnya. Sebaliknya, orang Betawi Kota ada yang menyukai jengkol, tetapi banyak pula yang tidak menyukainya. Bahan masakan yang disantap orang Betawi adalah apa yang disediakan alam yang terdapat di kebunnya. Misalnya, jantung pisang dapat dijadikan bahan uraban dan pete-petean (petai Cina) dapat dibuat sayur asem; atau sayuran berkuah kecap.

Kopi Jahe merupakan salah satu minuman andalan yang disajikan untuk mengusir dingin saat malam hari. Minuman ini terpengaruh oleh masyarakat Arab yang awalnya banyak berdiam di kawasan Pekojan, yang kini secara administratif masuk ke dalam wilayah Jakarta Barat. Meski di beberapa wilayah lain ada beberapa masyarakat yang juga mengenal sajian ini, namun bisa dibilang bahwa penyebaran Kopi Jahe terkonsentrasi di wilayah Betawi Tengah. Betawi Tengah di masa kolonial Belanda masuk dalam wilayah yang disebut Weltevreden dan Meester Cornelis. Kawasan yang berada dalam wilayah Betawi Tengah atau Betawi Kota ini mendapatkan pengaruh akulturasi yang sangat besar, mulai dari budaya Belanda, Tionghoa, Melayu, hingga Arab. Pada masa pemerintahan Belanda, wilayah Weltevreden ini berkembang pesat dan menjadi kawasan elit dengan tingkat modernitas yang tinggi. Hal ini membuat kebudayaan, termasuk kuliner, di wilayah Betawi Tengah/Kota memiliki ciri khas yang agak berbeda dengan wilayah Betawi pinggir dan Betawi pesisir.

Dalam segelas Kopi Jahe terdapat pengaruh Melayu dan Arab. Pengaruh Melayu tampak pada penggunaan daun pandan dan cengkih yang merupakan tanaman endemik dari Indonesia. Daun pandan memberikan sensasi aroma harum pada minuman sedangkan cengkih membuat Kopi Jahe bercita rasa sedikit pedas. Sedangkan pengaruh Arab tersebut dapat terlihat dalam penggunaan kapulaga yang merupakan rempah yang biasa digunakan oleh masyarakat Arab. Penggunaan kapulaga membuat minuman ini beraroma harum.

Sayangnya, Kopi Jahe kini bisa dibilang termasuk sebagai minuman langka, karena sudah tak mudah menemukannya lagi. Bahkan, di beberapa daerah asalnya pun kini sudah sulit ditemukan. Generasi penerus di masyarakat setempat pun perlahan mulai jarang membuatnya di rumah. Kebanyakan warung-warung makan Betawi juga tak banyak lagi yang menjual Kopi Jahe.

Ditinjau dari filosofinya, Kopi Jahe memiliki nilai filosfi yang tinggi. Salah satunya dapat dilihat dari fungsinya sebagai sajian khas saat perhelatan yang berhubungan dengan acara keagamaan. Saat perhelatan tersebut, warga masyarakat berkumpul di satu ruangan. Mereka saling bercakap-cakap bahkan hingga larut. Kopi Jahe dihidangkan untuk mengatasi rasa dingin di malam hari dan membuat obrolan di antara warga makin hangat. Ini karena stimulan kafein yang ada di dalam kopi yang membuat tubuh terasa bugar.

\section{Khasiat dan Kandungan Gizi Kopi Jahe}

Kopi Jahe nikmat diminum saat hari sedang dingin. Harum aroma kopi bercampur dengan aroma rempah yang direbus berbarengan dengan kopi. Kopi adalah bahan utama yang dipakai untuk membuat minuman ini. Minuman kopi dibuat dari hasil seduhan biji kopi yang sebelumnya telah disangrai dan dihaluskan hingga menjadi bubuk (Wikpedia). Tanaman kopi merupakan salah satu komoditas yang telah dibudidayakan di 50 negara. Varietas pohon kopi yang dikenal umum adalah kopi robusta (Coffee canephora) dan kopi arabika (Coffee arabica). 
Kopi sendiri memiliki senyawa kafein yang tinggi. Kafein adalah senyawa hasil metabolism sekunder golongan alkaloid dari tanaman kopi dan memiliki rasa yang pahit (Wikipedia). Kafein juga merupakan psikostimulan dan merupakan zat perangsang yang bisa meningkatkan konsentrasi, mengurangi rasa lelah serta dapat meningkatkan ingatan jangka panjang dan kerja otak. Bisa dibilang, kafein dalam kopi merupakan "obat legal" yang paling banyak dijual di dunia serta memiliki banyak manfaat (Kompas.com, 2018). Peminum kopi aktif yang meninggal akibat serangan jantung dan stroke berkurang sekitar $16 \%$. Selain itu, risiko kanker (prostat dan kolektoral) berkurang hingga 18\%. Bahkan risiko penyakit neurologis, seperti alzheimer dan parkinson juga berkurang secara signifikan pada peminum kopi. Kopi juga melindungi DNA. Biji kopi tak hanya mengandung kafein. Tapi, juga memiliki lebih dari 1.000 zat tanaman yang memiliki efek antioksidan, anti-inflamasi dan anti-kanker (Kompas.com, 2018).

Kombinasi rempah dan bumbunya menghasilkan paduan rasa yang kompleks tetapi harmonis. Penggunaan rempah dalam suatu makanan bisa menjadi rahasia kelezatan, tapi juga bisa jadi perusak rasa jika takarannya tidak pas. Terlalu banyak rempah atau kombinasi rempah yang tidak pas bisa membuat cita rasa hidangan jadi terasa seperti jamu.

Proses penyangraian selain memerlukan kesabaran juga membutuhkan pengalaman alias jam terbang. Sangrai adalah memasak tanpa minyak. Seperti halnya biji kopi yang akan dihaluskan, rempah-rempah pun perlu disangrai terlebih dahulu. Proses penyangraian pada rempah ini berguna untuk memunculkan dan memperkuat aroma khas yang akan dihasilkan (Syamsir, E., 2011). Kalau belum terbiasa, proses menyangrai malah bisa membuat rempah jadi gosong dan menjadi pahit sehingga akan memengaruhi cita rasa masakan yang dihasilkan. Dalam pembuatan Kopi Jahe, proses penyangraian juga dilakukan untuk jahe.

Bicara soal khasiat Kopi Jahe, tentu tak bisa lepas dari kandungan rempah yang digunakan dalam racikan bumbunya. Selain menyumbangkan flavor dalam masakan, banyak kandungan zat aktif dalam rempah yang memiliki khasiat sebagai antimikroba, antioksidan, dan manfaat lain yang baik untuk kesehatan. Manfaat beberapa jenis rempah yang biasa digunakan dalam masakan, dapat dilihat pada Tabel 1 (Syamsir, E., 2011).

Tabel 1. Manfaat dari Beberapa Jenis Rempah

\begin{tabular}{|c|c|c|}
\hline \multicolumn{2}{|c|}{ Manfaat } & \multirow[t]{2}{*}{ Contoh rempah } \\
\hline Langsung & Ikutan & \\
\hline Rasa & $\begin{array}{l}\text { Menutup rasa yang tidak } \\
\text { diinginkan }\end{array}$ & $\begin{array}{l}\text { Kemangi, lada hitam, kapulaga, serai, pekak } \\
\text { (bunga lawang) }\end{array}$ \\
\hline Aroma & $\begin{array}{l}\text { Meningkatkan selera/nafsu } \\
\text { makan }\end{array}$ & $\begin{array}{l}\text { Cengkih, jahe, daun kari, daun mint, pala, } \\
\text { kapulaga, kayu manis, daun pandan. }\end{array}$ \\
\hline Tekstur & $\begin{array}{l}\text { Membentuk konsistensi } \\
\text { makanan }\end{array}$ & $\begin{array}{l}\text { Biji mustard, bawang bombay, bawang merah, } \\
\text { biji wijen, kemiri, biji kenari. }\end{array}$ \\
\hline Warna & Memperbaiki tekstur & $\begin{array}{l}\text { Paprika, cabai, peterseli, kunyit, daun suji, kayu } \\
\text { secang }\end{array}$ \\
\hline Antimikroba & Pengawet & $\begin{array}{l}\text { Kayu manis, cengkih, jintan, oregano, kunyit, } \\
\text { daun pandan }\end{array}$ \\
\hline $\begin{array}{l}\text { Antioksidan, } \\
\text { komponen aktif } \\
\text { untuk kesehatan }\end{array}$ & $\begin{array}{lll}\text { Menjaga } & \text { kesehatan } & \text { dan } \\
\text { kebugaran } & & \end{array}$ & $\begin{array}{l}\text { Kayu manis, cengkih, jinten, jahe, kunyit, } \\
\text { bawang putih }\end{array}$ \\
\hline
\end{tabular}

Dari sejumlah rempah yang digunakan untuk membuat Kopi Jahe, ada beberapa jenis rempah yang digunakan, antara lain adalah jahe, cengkih, kapulaga, kayumanis, daun pandan. Seperti halnya rempahrempah lain, rempah ini juga memiliki khasiat yang baik untuk kesehatan.

Menurut situs daring Wikipedia, jahe (Zingiber officinale) adalah salah satu jenis tanaman yang banyak digunakan dalam industri jamu. Bagian yang utama yang digunakan adalah rimpangnya. Rimpang jahe berbentuk seperti jemari yang menggembung di ruas bagian tengahnya. Rasa dominan jahe adalah pedas karena adanya senyawa keton bernama zingeron. Jahe segar memiliki rasa yang lebih kuat jika dibandingkan dengan jahe bubuk. Kandungan gingerol jahe yang baik untuk ksehatan ini juga banyak terdapat pada jahe segar. Beberapa manfaat jahe adalah untuk memperlancar pencernaan berkat kandungan phenolic yang dapat meredakan gejala iritasi gastrointestinal. Jahe juga disebut sebagai carminative yang dapat membantu mengeluarkan gas berlebih dalam sistem pencernaan. Jahe juga dapat mengurangi mual, meminimalisir rasa sakit, mencegah kanker, juga membantu proses detoksifikasi tubuh. Selain itu jahe juga berkhasiat antiradang dan membantu menurunkan berat badan. 
Selain jahe, rempah lain yang digunakan dalam Kopi Jahe adalah kayumanis (Cinnamomum verum). Bagian yang digunakan adalah bagian kulit batangnya. Kayumanis memiliki aroma yang harum dengan cita rasa yang manis dan sedikit pedas. Sebagai bumbu, kayumanis sudah digunakan sejak zaman Mesir Kuno sekitar 5000 tahun yang lalu. Kayunanis juga memiliki banyak manfaat kesehatan. Di antaranya adalah mencegah kanker, antiradang, berguna untuk kesehatan otak, juga untuk mencegah penyakit diabetes. Selain itu kayumanis juga bermanfaat untuk kecantikan wajah seperti mencegah jerawat (Merdeka, 2018).

Kopi jahe juga menggunakan daun pandan wangi atau lebih populer disebut sebagai pandan (Panadanus amaryllifolius) sebagai salah satu rempah daun. Daun pandan akan memberikan aroma yang harum setelah minuman selesai direbus. Selain memberi aroma, daun pandan juga berkhasiat untuk menurunkan demam berkat kandugan minyak tannin, glikosida, dan alkaloid-nya. Pandan juga dapat mengatasi sembelit, menambah stamina, meringkan sakit kepala, menyembuhkan insomnia, meningkatkan nafsu makan, dan menghilangkan ketombe (Kumparan, 2018).

Rempah lainnya untuk membuat Kopi Jahe adalah cengkih dan kapulaga. Cengkih (Syzygium aromaticum) merupakan tanaman endemic asal Kepulauan Maluku, Indonesia. Cengkih akan memberi aroma harum dan rasa pedas pada masakan. Cengkih memiliki khasiat anti-inflamasi, meningkatkan sistem kekebalan tubuh, menyembuhkan infeksi saluran pernafasan, mengatur gula darah, melindungi hati, antikarsinogenik, dan memperbaiki pencernaan. Sedangkan kapulaga (E. cardamomum) merupakan tanaman asli benua Asia. Kapulaga juga akan memberikan aroma yang khas ke dalam makanan atau minuman yang menggunakannya. Khasiat kapulaga adalah untuk mengatasi rasa mulas, mengurangi batuk, menyembuhkan sakit mulut dan tenggorokan serta sembelit (Gardjito, M, dkk, 2017).

\section{Analisa Lingkungan Untuk Melihat Potensi Kopi Jahe Sebagai Oleh-Oleh Khas Betawi}

Salah satu kebutuhan pokok manusia adalah makanan dan minuman. Dalam usaha memenuhi kebutuhan tersebut bisa dilakukan dengan penganekaragaman jenis sajian. Usaha kuliner melihat peluang tersebut, sehingga bermunculanlah kuliner-kuliner yang menarik. Pada saat ini kuliner di Kota Jakarta semakin menghadapi persaingan yang tajam. Banyaknya bermunculan kedai-kedai minuman berwaralaba atau kedai minuman lokal membuat makin terpuruknya kharisma Kopi Jahe. Untuk itu Kopi Jahe sebagai minuman khas Betawi harus bisa mempertahankan diri dan sekaligus harus memenangkan persaingan. Perlu dilakukan identifikasi ancaman-ancaman dan peluang yang di hadapi, sehingga Kopi Jahe dapat mawas diri dan mampu menghadapinya. Lingkungan yang semakin kompleks tersebut menuntut perhatian banyak pihak terutama Pemerintah Kota Jakarta dan Perguruan Tinggi memberikan solusi terbaik.

Lingkungan yang dihadapi oleh Kopi Jahe terdiri dari lingkungan eksternal yang sulit dikendalikan. Termasuk didalamnya adalah adanya ancaman dan peluang usaha yang muncul dari pihak lain. Disamping itu Kopi Jahe ini juga mempunyai lingkungan internal yang dapat menghadapi ancaman tersebut. Sekaligus dapat meraih peluang yang muncul. Lingkungan internal ini lebih dapat dikendalikan dibandingkan dengan lingkungan eksternal tadi. Yang termasuk didalamnya adalah kekuatan dan kelemahan yang ada pada Kopi Jahe itu sendiri.

a. Lingkungan internal, terdiri dari kekuatan dan kelemahan.

Kekuatan yang dimiliki Kopi jahe adalah sebagai berikut:

- Rasa Kopi Jahe yang khas dan cocok dengan selera banyak orang

- Kopi Jahe menggunakan bahan-bahan lokal yang tersedia banyak di Betawi.

- Memiliki nilai budaya dan filosofi yang tinggi

- Merupakan perpaduan dari beberapa budaya.

Kelemahan yang juga dimiliki oleh Kopi Jahe adalah:

- Sedikitnya pedagang yang menjual Kopi Jahe

- Belum banyak dikenal masyarakat, khususnya generasi muda

- Resepnya belum populer dan referensinya terbatas.

b. Lingkungan eksternal, terdiri dari peluang dan ancaman

Peluang yang mungkin diraih oleh Kopi Jahe ini adalah:

- Semakin meningkatnya kunjungan wisatawan karena Kota Jakarta merupakan kota dengan wisata MICE yang komplet

- Semakin banyaknya orang mengenal Kopi Jahe karena adanya kemajuan teknologi informasi

- Adanya dukungan pemerintah untuk melakukan pengembangan pariwisata di Kota Jakarta

- Semakin berkembangnya wisata kuliner 
Sedangkan ancaman yang sedang menghadang usaha Kopi Jahe adalah:

- Bermunculannya kedai kopi waralaba baik dari luar negeri maupun dalam negeri, misalnya Starbucks, Coffee Bean \& Tea Leaf, Kopi Kulo, Kopi Kenangan, dll

Tabel.2 Analisa Faktor Eksternal Potensi Kopi Jahe

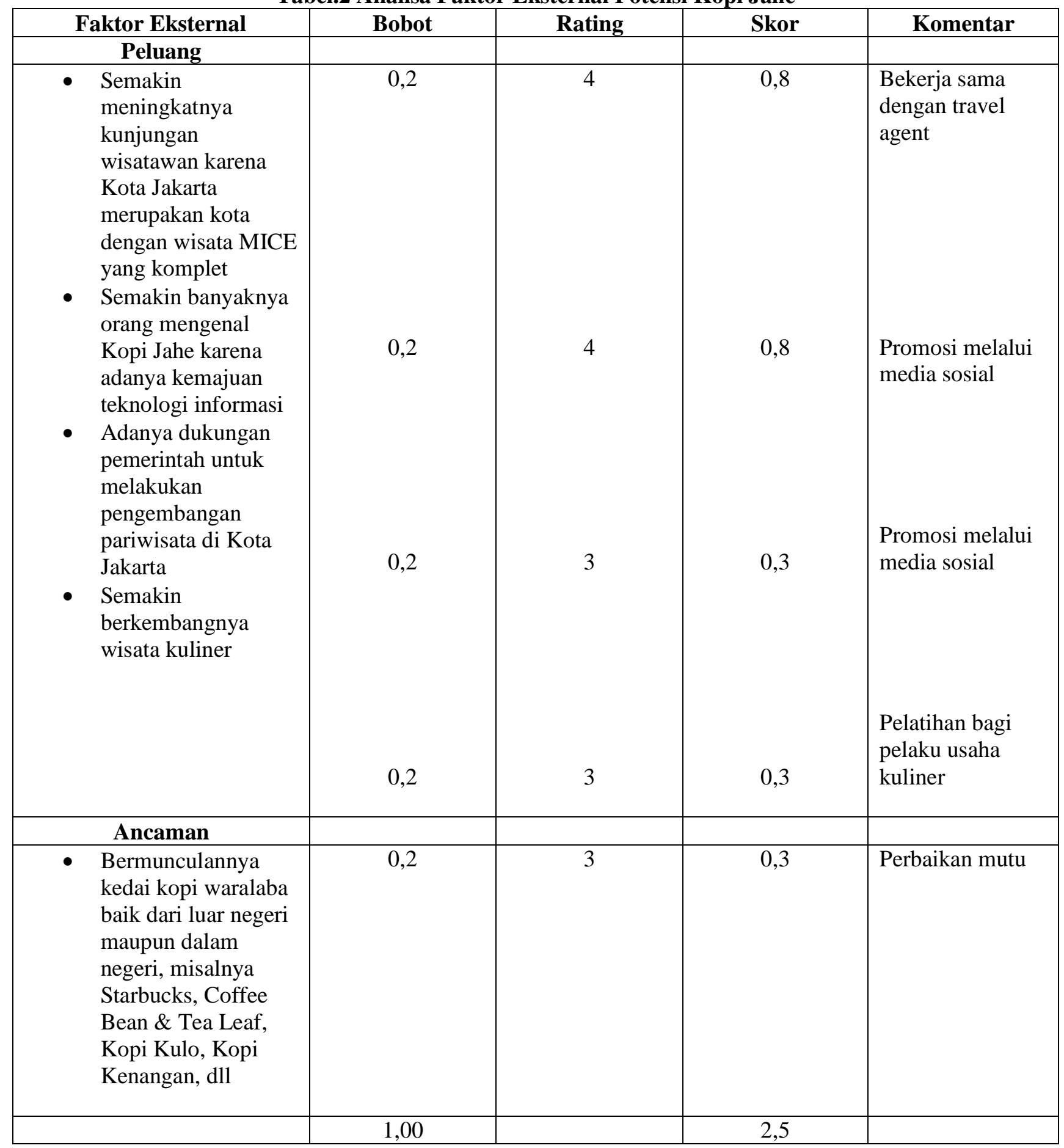


Tabel.3 Analisa Faktor Internal Potensi Kopi Jahe

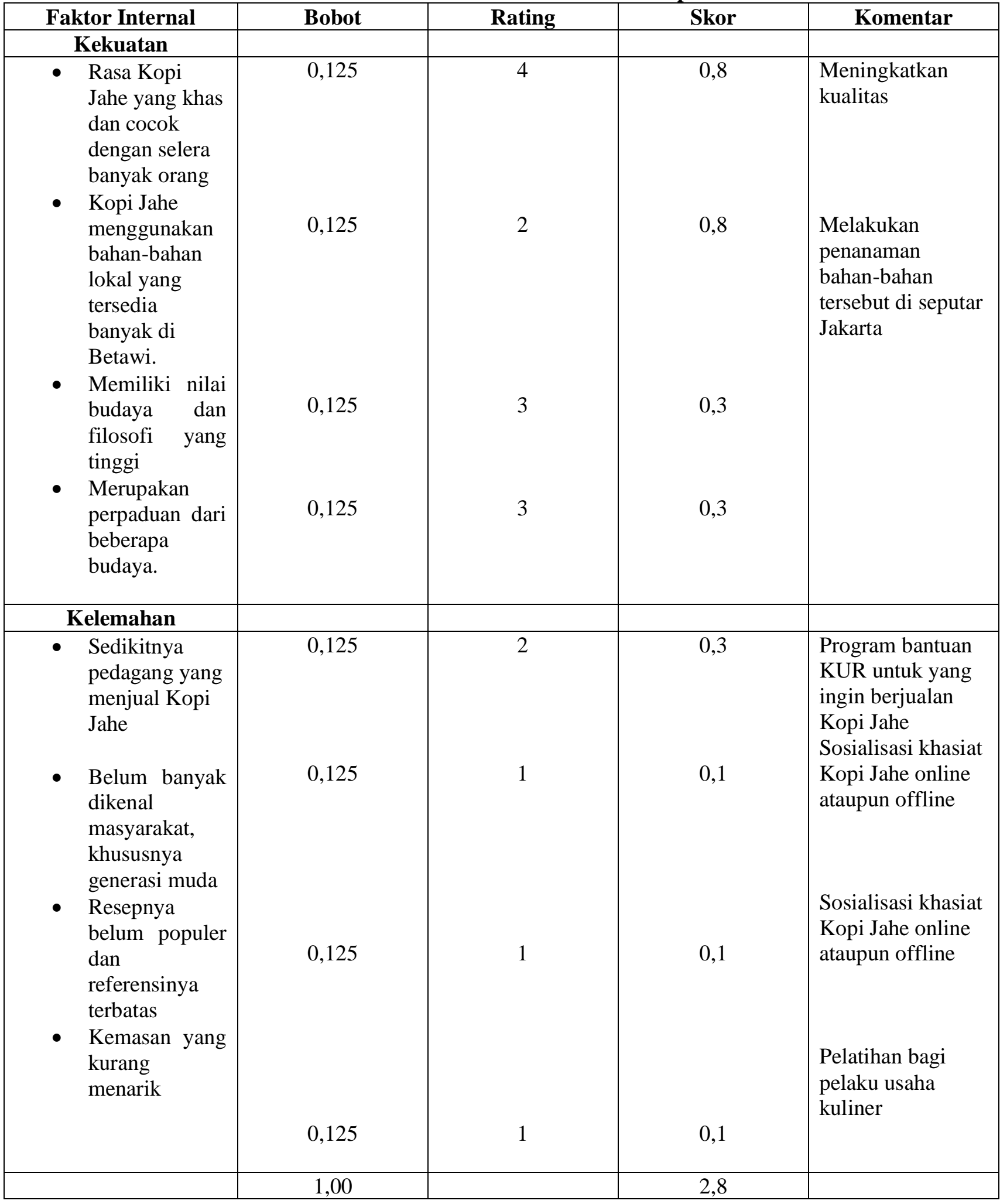




\section{SIMPULAN}

Berdasarkan hasil penelitian yang sudah dilakukan mengenai maka didapatkan kesimpulan sebagai berikut:

Dari informasi yang diperoleh, maka dapat disimpulkan bahwa Kopi Jahe mempunyai prospek bagus untuk dikembangkan sebagai oleh-oleh khas Betawi walaupun banyak menghadapi masalah-masalah yang menghambat perkembangannya. Dengan tersedianya informasi mengenai Kopi Jahe yang mudah didapatkan, orang lebih mudah mengenal dan mengetahui mengenai Kopi jahe sebagai salah satu minuman khas Betawi yang layak dijadikan sebagai oleh-oleh. Hal ini dapat menarik minat wisatawan yang lebih banyak. Diperlukan juga strategi pemasaran yang lebih cocok untuk memasarkan Kopi Jahe dan dukungan banyak pihak terutama pemerintah Kota Jakarta dan Perguruan Tinggi. Pemerintah Kota Jakarta dapat mendisain program pengembangan bagi Kopi Jahe sebagai minuman wajib di berbagai hotel dan rumah makan di Jakarta. Sedangkan Perguruan Tinggi memberikan dukungannya melalui pelatihan-pelatihan manajemen.

Langkah efektif yang dapat dilakukan agar Kopi Jahe diingat oleh banyak orang adalah dengan kehadirannya yang harus terus tersedia di tengah masyarakat. Dukungan dan peranan pemerintah, dalam hal ini adalah Pemerintah Kota DKI Jakarta, khususnya Dinas Pariwisata dan Kebudayaan, sangat diperlukan dalam bentuk:

1. Sebagai motivator, memberikan motivasi dan himbauan kepada pengusaha kuliner di Jakarta untuk memasukkan Kopi Jahe sebagai salah satu menu yang ditawarkan.

2. Sebagai fasilitator, memberikan kesempatan dan memfasilitasi kegiatan yang mendukung langkah promosi seperti pembuatan buku resep Kopi Jahe dan masakan Betawi lain yang mulai langka, pengadaan demo masak dan sosialisasi Kopi Jahe kepada masyarakat, dan lainnya.

\section{Buku}

\section{DAFTAR PUSTAKA}

Indonesia, Akademi Kuliner. 2016. Kuliner Betawi: Selaksa Rasa Dan Cerita. Jakarta: PT Gramedia Pustaka Utama.

Gardjito, Murdijati, dkk. 2017. Profil Struktur, Bumbu, dan Bahan dalam Kuliner Indonesia. Yogyakarta: Gajah Mada University Press.

\section{Artikel Daring}

NN. Tanpa Tahun. Kopi Jahe. https://jakarta.go.id/artikel/konten/1883/kopi-jahe. Diakses pada 30 Desember 2018.

Anggraini, Ariska Puspita. 2018. Apakah Kopi Benar-Benar Menyehatkan.

https://lifestyle.kompas.com/read/2018/09/04/161600920/apakah-kopi-benar-benar-menyehatkan-. Diakses pada 1 Januari 2019.

Kusumaningrum, Febriantina Diah. 2018. Manfaat Kayumanis. https://www.merdeka.com/sehat/manfaatkayu-manis-kln.html. Diakses pada 30 Desember 2018.

Joseph. Novita. Tanpa Tahun. 6 Manfaat Jahe Bagi Kesehatan. https://hellosehat.com/hidup-sehat/faktaunik/6-manfaat-jahe-bagi-kesehatan/. Diakses pada 30 Desember 2018.

Tanpa Nama. Tanpa Tahun. Tak Hanya Wangi Ini 7 Manfaat Kesehatan Daun Pandan. https://kumparan.com/@ kumparanfood/tak-hanya-wangi-ini-7-manfaat-kesehatan-daun-pandan. Diakses pada 30 Desember 2018.

Tanpa Nama. Tanpa Tahun. Manfaat Cengkih Untuk Kesehatan. http://www.tribunnews.com/kesehatan/2018/11/12/manfaat-cengkih-untuk-kesehatan. Diakses pada 30 Desember 2018.

Etika, Nimas Mita. Tanpa Tahun. Manfaat Kapulaga Adalah. https://hellosehat.com/herbal/manfaatkapulaga-adalah/. Diakses pada 30 Desember 2018.

Thalita, Tengku. Tanpa Tahun, Makalah Kuliner Betawi. https://www.academia.edu/24447880/Makalah_Kuliner_Betawi. Diakses pada 30 Desember 2018.

Ansyari, Syahrul. 2015. Mengenal Peninggalan Orang Arab Di Kampung Pekojan. https://www.viva.co.id/berita/metro/615120-mengenal-peninggalan-orang-arab-di-kampung-pekojan. Diakses pada 30 Desember 2018. 